\title{
ІСНУЮЧІ ЕКСПЕРИМЕНТАЛЬНІ МОДЕЛІ ВЕНОЗНОГО ТРОМБОЗУ (ОГЛЯД ЛІТЕРАТУРИ)
}

\author{
В. В. Бойко, В. О. Прасол, Д. В. Оклей, \\ І. А. Тарабан, П. О. Болдижар ${ }^{1}$ \\ ДУ «Інститут загальної та невідкладної хірургії імені В. Т. Зайцева НАМН України» \\ ${ }^{1}$ Ужгородський національний університет
}

\begin{abstract}
На підставі аналізу великого обсягу даних літератури, присвячених моделюванню тромботичних станів в експериментах на лабораторних тваринах, зроблено висновок, що в даний час $є$ опис безлічі моделей венозного тромбозу. Однак найпростішим, відтвореним і найменш травматичним є метод S. Wessler і співавт. (1959): поєднання венозного застою і гіперкоагуляції за рахунок введення активованого фрактора згортання.
\end{abstract}

Ключові слова: венозний тромбоз, експериментальна модель.

\section{ИМЕЮЩИЕСЯ ЭКСПЕРИМЕНТАЛЬНЫЕ МОДЕЛИ ВЕНОЗНОГО ТРОМБОЗА (ОБЗОР ЛИТЕРАТУРЫ)}

\author{
В. В. Бойко, В. А. Прасол, Д. В. Оклей, \\ И. А. Тарабан, П. А. Болдижар ${ }^{1}$ \\ ГУ «Институт общей и неотложной хирургии имени В. Т. Зайцева НАМН Украины» \\ 1Ужгородский национальный университет
}

\begin{abstract}
На основании анализа большого объема данных литературы, посвященных моделированию тромботических состояний в экспериментах на лабораторных животных, сделан вывод, что в настоящее время описано множество моделей венозного тромбоза. Однако самым простым, воспроизводимым и наименее травматичным является метод S. Wessler и соавт. (1959): сочетание венозного застоя и гиперкоагуляции за счет введения активированного фактора свертывания.
\end{abstract}

Ключевые слова: венозный тромбоз, экспериментальная модель.

\section{EXISTING EXPERIMENTAL MODELS OF VENOUS THROMBOSIS (REVIEW)}

\section{V. Boiko, V. O. Prasol, D. V. Oklei,} I. A. Taraban, P. O. Boldizhar ${ }^{1}$

\author{
SI «Institute of General and Emergency Surgery named V. T. Zaytsev NAMS of Ukraine»
}

${ }^{1}$ Uzhgorod National University

\begin{abstract}
Based on the analysis of a large volume of the literature data concerning simulation of thrombotic conditions in laboratory animals under experimental conditions, the authors discuss various models of venous thrombosis. The method proposed by S. Wessler et al. (1959) is considered to be the simplest, most readily reproducible, and least invasive one. It consists of a combination of venous hyperemia and hypercoagulation induced by the administration of an activated coagulation factor.
\end{abstract}

Key words: venous thrombosis, experimental method. 
Вступ. Необхідність моделювання венозного тромбозу в експерименті найчастіше пов’язана 3 вивченням антитромботичної активності різних лікарських речовин і ефективності різних хірургічних маніпуляцій. Для цих цілей дослідники в основному використовують метод S. Wessler і співавт. [40] (поєднання застою і гіперкоагуляції) в різних його модифікаціях. У класичній моделі S. Wessler і співавт. [40] на кроликах стану гіперкоагуляції досягають за рахунок введення гетерологичної сироватки (наприклад, сироватки крові людини) або активованого фактора згортання, після чого створюється венозний стаз.

Основна частина. Пізніше була показана можливість використання цього методу на інших тваринах (собаках і щурах) і з іншими агентами, що активують тромбоутворення. Зокрема, J. M. Herbert i cniвавm. [20] викликали венозний тромбоз перев’язкою нижньої порожнистої вени у щурів з попередніми внутрішньовенним введенням тканинного тромбопластину. L. Kaptanoglu i cniвавт. [33] формували тромб в експерименті на щурах в області черевної нижньої порожнистої вени також за допомогою методу S. Wessler.

M. М. Дрозд і співавт. [2, 3] через певні проміжки після введення досліджуваної антитромботичної речовини активували систему згортання сироваткою людини. Потім перев’язували сантиметрову ділянку вени, яку не використали для введення речовин.

Для створення венозного тромбозу також застосовують тільки перев’язку венозного стовбура або установку на нього затиску [7-9, 15, 16, 18, 19, 22, 28, 36, 37].

J. Zhou i cniвaвm. [21] для отримання тромбозу нижньої порожнистої вени у щурів здійснювали її перев’язку на період від 15 до 60 хв. Легування призводило до швидкої дилатації нижньої порожнистої вени, і через 60 хв. тромби були виявлені у всіх щурів. Невеликі тромби були виявлені у більшості тварин вже через 15 хв. після перев'язки. Тромби були багаті фібрином 3 агрегованими тромбоцитами, з лейкоцитами й еритроцитами. Більшість тромбів виникало на місці пошкодження ендотелію. Іммуногістохімічний аналіз показав експресію тканинного фактора ендотеліальними клітинами і лейкоцитами.

В літературі [30, 34] є рекомендації щодо часткової перев’язки магістральної вени. P. Pottier $i$ співавт. [10] розробили першу модель на тваринах, в якій венозний застій може бути відкаліброва- ний шляхом зміни ступеня стенозу нижньої порожнистої вени. У моделі присутній попередній тромботичний стан у щурів, створений за рахунок часткової перев’язки нижньої порожнистої вени.

I. С. Іванов і співавт. [1] в своїх дослідженнях застосовували метод, описаний I. Reyers i співавт. [31]. Для цього тварин вводили в наркоз (внутрішньочеревно уретан, 1 г/кг), розкривали черевну порожнину, виділяли порожнисту вену i перев’ язували їі бавовняною ниткою дистальніше лівої ниркової вени, після чого черевну порожнину пошарово ушивали. Через 2 год. проводили лапаротомію, ділянку вени довжиною 7 мм резеціювали. Тромб виділяли з просвіту судини, надлишок крові видаляли фільтрувальним папером. Оцінювали масу вологого тромбу.

J. Millet i cniвавm. [27] поєднували сольові промивання з наступним венозним стазом. Було показано, що промивка індукує дискретні ендотеліальні пошкодження. При цьому максимальної маси тромб досягав через 15 хв. впливу. А в 1996 р. J. Millet i співавт. [14] використовували гомологічну сироватку як тромбогенний агент в експериментах на щурах.

K. Ungersböck i cniвавт. [35] моделювали тромбоз верхнього сагітального синуса у щурів шляхом повільної ін'єкції суспензії каолін-кефалін після передньої і задньої перев’язки сагітального синуса. Місцевий мозковий кровотік вимірювали за допомогою лазерної допплерівської флоуметрии. Дослідження показали, що венозний синус-тромбоз розвивається поступово, при цьому основні паренхіматозні ушкодження головного мозку проявляються тільки тоді, коли тромб поширюється до кортикальних вен.

Була розроблена модель оборотного тромбозу верхнього сагітального синуса у щурів. Тромбоз викликали місцевим застосуванням хлориду заліза. Оклюзія була підтверджена магнітно-резонансною ангіографією. За відсутності лікування розвивався дифузний набряк мозку без інфарктів і кровотеч [23]. Подібну методику для отримання тромбозу верхнього сагітального синуса у мишей (із застосуванням FeCl3 і фотоактивації флюоресцеїна) використовували в своїх експериментах M. Nagai і співавт. [32].

Також для моделювання судинних тромбозів застосовують різні травматичні моделі. Зокрема, P. Gorman i cniвавm. [12] моделювали тромбози шкірних судин у щурів шляхом створення опікового «гребеня» $з$ ураженням на всю товщину на спині за допомогою латунного бруска. 
Останнім часом для індукції венозного тромбозу в експерименті часто застосовується лазерний вплив. У процесі використання теплового лазера металевий наконечник лазерного катетера («гарячий наконечник») вводили транс'югулярно в дистальний відділ нижньої порожнистої вени. Пошкодження здійснювали лазерними імпульсами різної інтенсивності (4-7 Вт). Однак на підставі результатів роботи був зроблений висновок про те, що діапазон потужності термічного лазерного впливу, який викликає тромбоз або ж теплову перфорацію судини, занадто вузький, щоб забезпечити безпечне клінічне застосування цього методу [26].

Для отримання тромбозу в дрібних брижових судинах (15-25 мкм), в тому числі венулах, з метою вивчення антитромботичних препаратів і реакції тромбоцитів, використовували аргоновий лазер. Лазерний промінь індукував травму судинної стінки, пов'язану з пошкодженням ендотеліальних клітин. Тромб формувався протягом декількох секунд після лазерної травми і швидко зростав. Агрегати могли бути вимиті потоком крові, але тромб формувався знову протягом хвилини. Було зроблено висновок про особливу роль тромбоцитів в венозному тромбозі, індукованому лазерним променем [5]. Дана модель була застосована для оцінки антикоагулянтного ефекту ацетилсаліцилової кислоти в надмалих дозах $[4,6,11]$.

F. Doutremepuich i співавт. [17] вивчали вплив базового рівня фібриногену в плазмі крові на ризик тромбоемболічних ускладнень в патогенезі післяопераційного або посттравматичного тромбозу. Метою експерименту була оцінка наслідків впливу різних доз фібриногену на утворення тромбів у щурів. Для формування тромбу пошкоджували ендотеліальні клітини лазером і вводили фібриноген через вени пеніса в різних дозах (50, 100 i 200 мг/кг). Результат оцінювали через 120 хв після ін'єкції. Показано, що вплив фібриногену збільшує

\section{Література.}

1. Антитромбогенная активность липоверина на модели венозного тромбоза у крыс / И. С. Иванов, А. В. Сидехменова, В. И. Смольякова [и др.] // Фармакология. - 2010. - № 11. - С. 590-596.

2. Антитромботическая активность отечественного препарата «антитромбин III» на модели индуцированного венозного тромбоза / Н. Н. Дрозд, В. А. Макаров, Н. Т. Мифтахова [и др.] // Бюллетень экспериментальной биологии и медицины. - 2006. - Т. 142, № 7. - Р. 75-77. кількість емболій і тривалість емболізації. Таким чином, існує позитивна кореляція між підвищенням концентрації фібриногену в плазмі крові і високим ризиком тромбоемболічних ускладнень.

Y. Saito i співавт. [13] використовували експериментальну модель венозної оклюзії при фотодинамічному тромбозі у щурів. Після анестезії щури отримували внутрішньочеревно 0,2 мл $10 \%$ натрію флюоресцеїна за 15 хв. до лазерної обробки. Вплив здійснювали синьо-зеленим аргоновим лазером протягом 1 с при наступних параметрах: 50 мкм і 50-100 мВт. Вибрані ділянки вен поруч із зоровим нервом були фотокоагульовані через лінзу в 78 діоптрій. Через 10-30 хв. після обробки в секторах сітківки, пов'язаних з оклюзією вен, розвинувся набряк. Протягом 12 год. набряк перейшов в бульозне відшарування сітківки з крововиливами. Набряк сітківки тривав 3-10 діб.

Також для формування тромбозу проводили фотокоагуляцію аргоновим лазером основних вен сітківки, прилеглих до зорового нерву, з попереднім введенням бенгальського рожевого (40 мг/ кг) в хвостову вену [24]. Для індукції мікровенозного тромбозу сітківки щурів (фотодинамічний тромбоз) використовували фотосенсибілізатор, одночасно з цим була зроблена флуоресцентна ангіографія [29].

Висновки. В доступній літературі міститься опис безлічі експериментальних моделей венозного тромбозу. Однак найпростішим, відтвореним і найменш травматичним є метод $S$. Wessler і співавт. (1959): поєднання венозного застою (наприклад, легування вени) і гіперкоагуляції, за рахунок введення активованого фактора згортання (наприклад, тромбіну). У той же час, тривають спроби створення нових, найбільш оптимальних експериментальних моделей венозного тромбозу для вивчення антитромботичної активності різних фармакологічних препаратів [25, 38, 39].

3. Антитромботическая активность парааминобензойной кислоты / Н. Н. Дрозд, В. А. Макаров, Н. Т. Мифтахова [и др.] // Экспериментальная и клиническая фармакология. - 2000. - Т. 63, № 3. - Р. 40-44.

4. Aguejouf O. Effects of external electrical stimulation on laser-beam-induced experimental thrombosis / O. Aguejouf, F. Doutremepuich, C. Doutremepuich // Pathophysiol. Haemost. Thromb. - 2006. - Vol. 35, No 5. - P. 364-369. 5. Antithrombotic effects of aspirin and LMWH in a laserinduced model of arterials and venous thrombosis / P. Imbault, 
F. Doutremepuich, O. Aguejouf, C. Doutremepuich // Thromb. Res. - 1996. - Vol. 82, No 6. - P. 469-478.

6. Azougagh O. F. Experimental models of venous thrombosis / O. F. Azougagh, F. Doutremepuich, C. Doutremepuich // Ann. Cardiol. Angeiol. (Paris). - 1995. - Vol. 44, No 6. P. 288-298.

7. Comparative study on the effects of a low molecular weight heparin (CY 216) and standard heparin in low dosage on experimental venous thrombosis / C. Doutremepuich, F. Bousquet, G. L. Gestreau [et al.] // Haemostasis. - 1987. - Vol. 17, No 4. - P. 201-205.

8. Deep vein thrombosis resolution is not accelerated with increased neovascularization / M. R. Varma, D. M. Moaveni, N. A. Dewyer [et al.] // J. Vasc. Surg. - 2004. - Vol. 40, No 3. - P. 536-542.

9. Detection of perivenous inflammation in a rat model of venous thrombosis using MRV / F. J. Londy, A. M. Kadell, S. K. Wrobleski [et al.] // J. Invest. Surg. - 1999. - Vol. 12, No 3. - P. 151-156.

10. Development of an experimental model of prethrombosis in rats based on Wessler's principle using a calibrated venous stasis / P. Pottier, B. Planchon, F.Truchaud [et al.] // Blood Coagul. Fibrinolysis. - 2003. - Vol. 14, No 1. - P. 3-9.

11. Doutremepuich C. Effects of ultra-low-dose aspirin on embolization in a model of laser-induced thrombus formation / C. Doutremepuich, O. Aguejouf, P. Belon // Semin. Thromb. Hemost. - 1996. - Vol. 22, Suppl. 1. - P. 67-70.

12. Effects of topical nitroglycerin and flurbiprofen in the rat comb burn model / P. J. Gorman, G. Saggers, P. Ehrlich [et al.] // Ann. Plast. Surg. - 1999. - Vol. 42, No 5. - P. 529-532. 13. Experimental preretinal neovascularization by laserinduced venous thrombosis in rats / Y. Saito, L. Park, S. A. Skolik [et al.] // Curr. Eye Res. - 1997. - Vol. 16, No 1. - P. 26-33.

14. Experimental venous thrombosis induced by homologous serum in the rat / J. Millet, M. Vaillot, J. Theveniaux, N. L. Brown // Thromb. Res. - 1996. - Vol. 8, No 4. P. 497-502.

15. Experimental venous thrombosis in rats treated with heparin and a low molecular weight heparin fraction / C. Doutremepuich, J. L. Gestreau, M. O. Maury [et al.] // Haemostasis. - 1983. - Vol. 13, No 2. - P. 109-112.

16. Expression changes and roles of matrix metalloproteinases in a rat model of traumatic deep vein thrombosis / Y. B. Zhang, W. Li, L. Q. Yao [et al.] // Clin. J. Traumatol. - 2010. - Vol. 13, No 3. - P. 188-192.

17. Fibrinogen as a factor of thrombosis: experimental study / F. Doutremepuich, O. Aguejouf, E. Belougne-Malfatti, C. Doutremepuich // Thromb. Res. - 1998. - Vol. 90, No 2. - P. 57-64.

18. Gender differences in deep venous thrombosis in a rat model: a preliminary study / L. A. van Langevelde, S. E. Anchill, S. K. Wrobleski [et al.] // Comp. Med. - 2005. - Vol. 55, No 1. - P. 55-60.

19. Gene expression profile related to inflammation in rat model of traumatic deep vein thrombosis / C. Q. Zhang,
H. Huang, Z. Zhao [et al.] // Chin. J. Traumatol. - 2007. Vol. 10, No 4. - P. 206-212.

20. Herbert J. M. Importance of platelets in experimental venous thrombosis in the rat / J. M. Herbert, A. Bernat, J. P. Maffrand // Blood. - 1992. - Vol. 80, No 9. - P. 22812286.

21. Inferior vena cava ligation rapidly induces tissue factor expression and venous thrombosis in rats / J. Zhou, L. May, P. Liao [et al.] // Arterioscler. Thromb. Vasc. Biol. - 2009. - Vol. 29, No 6. - P. 863-869.

22. Influence of heparin and a low molecular weight heparin fraction of the leukocytes in an experimental venous thrombosis model / C. Doutremepuich, F. Toulemonde, O. de Seze [et al.] // J. Leukoc. Biol. - 1987. - Vol. 42, No 6. - P. 628-631.

23. Is heparin treatment the optimal management for cerebral venous thrombosis? Effect of abciximab, recombinant tissue plasminogen activator, and enoxaparin in experimentally induced superior sagittal sinus thrombosis / C. Röttger, K. Madlener, M. Heil [et al.] // Stroke. - 2005. - Vol. 36, No 4. - P. 841-846.

24. Kang S. G. Experimental preretinal neovascularization by laser-induced thrombosis in albino rats / S. G. Kang, H. Chung, J. Y. Hyon // Korean J. Ophthalmol. - 1999. Vol. 13, No 2. - P. 65-70.

25. Kretz C. A. Tissue factor and thrombosis models / C. A. Kretz, N. Vaezzadeh, P. L. Gross // Arterioscler. Thromb. Vasc. Biol. - 2010. - Vol. 30, No 5. - P. 900-908. 26. Laser thermal venous obliteration: experimental results in the rat model / D. Vorwerk, B. Vollmer, S. Handt, R. W. Günther // Rofo. - 1994. - Vol. 160, No 1. - P. 84-88. 27. Millet J. A new experimental model of venous thrombosis in rats involving partial stasis and slight endothelium alterations / J. Millet, J. Theveniauxa, M. Pascala // Thromb. Res. - 1987. - Vol. 45, Iss. 2. - P. 123-133.

28. Prevention of venous thrombosis by preoperative glycyrrhizin infusion in a rat model / N. Nakata, Y. Kira, Y. Yabunaka, K. Takaoka // J. Orthop. Sci. - 2008. - Vol. 13, No 5. - P. 456-462.

29. Quantitative evaluation for blood-retinal barrier breakdown in experimental retinal vein occlusion produced by photodynamic thrombosis using a new photosensitizer / Y. Ieki, H. Nishiwaki, S. Miura [et al.] // Curr. Eye Res. 2002. - Vol. 25, No 5. - P. 317-323.

30. Recruitment of labelled monocytes by experimental venous thrombosis / C. L. McGuinness, J. Humphries, M. Waltham [et al.] // Thromb. Haemost. - 2001. - Vol. 85, No 6. - P. 1018-1024.

31. Reyers I. Venostasis-induced thrombosis in rats is not influenced by circulating platelet or leukocyte number / I. Reyers, G. de Gaetano, M. B. Donati / Agents Actions. - 1989. - Vol. 28, No 1-2. - P. 137-141.

32. Role of coagulation factors in cerebral venous sinus and cerebral microvascular thrombosis / M. Nagai, C. E. Yilmaz, D. Kirchhofer [et al.] // Neurosurgery. - 2010. - Vol. 66, No 3. - P. 560-565. 
33. The effect of taurolidine on experimental thrombus formation / L. Kaptanoglu, H. F. Kucuk, E. Colak [et al.] // Eur. J. Pharmacol. - 2008. - Vol. 578, No 2-3. - P. 238-241. 34. Transplantation of VEGF165-gene-transfected endothelial progenitor cells in the treatment of chronic venous thrombosis in rats / Q. Y. Meng, X. Q. Li, X. B. Yu [et al.] // Chin. Med. J. (Engl.). - 2010. - Vol. 23, No 4. P. 471-477.

35. Ungersböck K. Cerebral blood flow alterations in a rat model of cerebral sinus thrombosis / K. Ungersböck, A. Heimann, O. Kempski // Stroke. - 1993. - Vol. 24, No 4. - P. 563-569.

36. Vein wall re-endothelialization after deep vein thrombosis is improved with low-molecular-weight heparin / D. K. Moaveni, E. M. Lynch, C. Luke [et al.] // J. Vasc. Surg. - 2008. - Vol. 47, No 3. - P. 616-624.

37. Vein wall remodeling after deep vein thrombosis: differential effects of low molecular weight heparin and doxycycline / V. Sood, C. Luke, E. Miller [et al.] // Ann. Vasc. Surg. - 2010. - Vol. 24, No 2. - P. 233-241.

38. Venous thrombosis and cancer: from mouse models to clinical trials / Y. Hisada, J. E. Geddings, C. Ay, N. Mackman // J. Thromb. Haemost. - 2015. - Vol. 13. - P. 1372-1382. 39. Weitz J. I. New antithrombotic drugs: antithrombotic therapy and prevention of thrombosis, 9th ed. : American College of Chest Physicians Evidence-Based Clinical Practice Guidelines / J. I. Weitz, J. W. Eikelboom, M. M. Samama // Chest. - 2012. - Vol. 141, Suppl. 2. P. e120S-e151S.

40. Wessler S. Biological assay of a thrombosis inducing activity in human serum / S. Wessler, S. M. Reimer, M. C. Sheps // J. Appl. Physiol. - 1959. - Vol. 14. P. 943-946.

\section{References.}

1. Ivanov, I. S., Sidekhmenova, A. V., Smol'yakova, V. I., Tyukavkina, N. A., Plotnikov, M. B. (2010). Antitrombogennaya aktivnost' lipoverina na modeli venoznogo tromboza u krys [Anti-thrombogenic activity of lipoverin on venous thrombosis model in rats]. Farmakologiya (Pharmacology), 11, 590-596 [In Russian].

2. Drozd, N. N., Makarov, V. A., Miftakhova, N. T., Dereza, T. L., Azhigirova, M. A. (2006). Antitromboticheskaya aktivnost' otechestvennogo preparata «antitrombin III» na modeli indutsirovannogo venoznogo tromboza [Antithrombotic activity of domestic preparation «antithrombin III» on the model of induced venous thrombosis]. Byulleten' eksperimental'noi biologii i meditsiny (Bulletin of Experimental Biology and Medicine), 142(7), 75-77 [In Russian].

3. Drozd, N. N., Makarov, V. A., Miftakhova, N. T., Kalugin, S. A., Stroeva, O. G., Akberova, S. I. (2000). Antitromboticheskaya aktivnost' paraaminobenzoinoi kisloty [The antithrombotic activity of P-aminobenzoic acid]. Eksperimental'naya i klinicheskaya farmakologiya (Russian
Journal of Experimental and Clinical Pharmacology), 63(3), 40-44 [In Russian].

4. Aguejouf, O., Doutremepuich, F., Doutremepuich, C. (2006). Effects of external electrical stimulation on laserbeam-induced experimental thrombosis. Pathophysiol. Haemost. Thromb., 35(5), 364-369. doi: 10.1159/000097690 5. Imbault, P., Doutremepuich, F., Aguejouf, O., Doutremepuich, C. (1996). Antithrombotic effects of aspirin and LMWH in a laser-induced model of arterials and venous thrombosis. Thromb. Res., 82(6), 469-478.

6. Azougagh, O. F., Doutremepuich, F., Doutremepuich, C. (1995). Experimental models of venous thrombosis. Ann. Cardiol. Angeiol. (Paris), 44(6), 288-298.

7. Doutremepuich, C., Bousquet, F., Gestreau, G. L., Toulemonde, F., Bayrou, B. (1987). Comparative study on the effects of a low molecular weight heparin (CY 216) and standard heparin in low dosage on experimental venous thrombosis. Haemostasis, 17(4), 201-205.

8. Varma, M. R., Moaveni, D. M., Dewyer, N. A., Varga, A. J., Deatrick, K. B., Kunkel, S. L., ... Henke, P. K. (2004). Deep vein thrombosis resolution is not accelerated with increased neovascularization. J. Vasc. Surg., 40(3), 536-542. doi: 10.1016/j.jvs.2004.05.023

9. Londy, F. J., Kadell, A. M., Wrobleski, S. K., Prince, M. R., Strieter, R. M., Wakefield, T. W. (1999). Detection of perivenous inflammation in a rat model of venous thrombosis using MRV. J. Invest. Surg., 12(3), 151-156.

10. Pottier, P., Planchon, B., Truchaud, F., Leftheriotis, G., Herbert, J. M., Bressolette, L., ... Passuti, N. (2003). Development of an experimental model of prethrombosis in rats based on Wessler's principle using a calibrated venous stasis. Blood Coagul. Fibrinolysis, 14(1), 3-9. doi: 10.1097/01.mbc.0000046184.72384.2c

11. Doutremepuich, C., Aguejouf, O., Belon, P. (1996). Effects of ultra-low-dose aspirin on embolization in a model of laser-induced thrombus formation. Semin. Thromb. Hemost., 22(Suppl. 1), 67-70.

12. Gorman, P. J., Saggers, G., Ehrlich, P., Mackay, D. R., Graham, W. P. 3rd. (1999). Effects of topical nitroglycerin and flurbiprofen in the rat comb burn model. Ann. Plast. Surg., 42(5), 529-532.

13. Saito, Y., Park, L., Skolik, S. A., Alfaro, D. V., Chaudhry, N. A., Barnstable, C. J., Liggett, P. E. (1997). Experimental preretinal neovascularization by laser-induced venous thrombosis in rats. Curr. Eye Res., 16(1), 26-33.

14. Millet, J., Vaillot, M., Theveniaux, J., Brown, N. L. (1996). Experimental venous thrombosis induced by homologous serum in the rat. Thromb. Res., 8(4), 497-502.

15. Doutremepuich, C., Gestreau, J. L., Maury, M. O. Quilichini, R., Boisseau, M. R., Toulemonde, F., Vairel, E. (1983). Experimental venous thrombosis in rats treated with heparin and a low molecular weight heparin fraction. Haemostasis, 13(2), 109-112.

16. Zhang, Y. B., Li, W., Yao, L. Q., Zhao, X. L., Wang, B., Li, H. K., ... Zhang, X. X. (2010). Expression changes and 
roles of matrix metalloproteinases in a rat model of traumatic deep vein thrombosis. Clin. J. Traumatol., 13(3), 188-192. 17. Doutremepuich, F., Aguejouf, O., Belougne-Malfatti, E., Doutremepuich, C. (1998). Fibrinogen as a factor of thrombosis: experimental study. Thromb. Res., 90(2), 57-64. 18. Langevelde van, L. A., Anchill, S. E., Wrobleski, S. K., Linn, M. J., Wakefield, T. W., Myers, D. D. Jr. (2005). Gender differences in deep venous thrombosis in a rat model: a preliminary study. Comp. Med., 55(1), 55-60.

19. Zhang, C. Q., Huang, H., Zhao, Z., Tang, X. Z., Wang, B., He, F. ... Li, S. H. (2007). Gene expression profile related to inflammation in rat model of traumatic deep vein thrombosis. Chin. J. Traumatol., 10(4), 206-212.

20. Herbert, J. M., Bernat, A., Maffrand, J. P. (1992). Importance of platelets in experimental venous thrombosis in the rat. Blood, 80(9), 2281-2286.

21. Zhou, J., May, L., Liao, P., Gross, P. L., Weitz, J. I. (2009). Inferior vena cava ligation rapidly induces tissue factor expression and venous thrombosis in rats. Arterioscler. Thromb. Vasc. Biol., 29(6), 863-869.

22. Doutremepuich, C., Toulemonde, F., de Seze, O., Pereira, F., Anne, M. C., Doutremepuich, F. (1987). Influence of heparin and a low molecular weight heparin fraction of the leukocytes in an experimental venous thrombosis model. J. Leukoc. Biol., 42(6), 628-631.

23. Röttger, C., Madlener, K., Heil, M., Gerriets, T., Walberer, M., Wessels, T., ... Stolz, E. (2005). Is heparin treatment the optimal management for cerebral venous thrombosis? Effect of abciximab, recombinant tissue plasminogen activator, and enoxaparin in experimentally induced superior sagittal sinus thrombosis. Stroke, 36(4), 841-846. doi: 10.1161/01.STR.0000157663.43209.a2

24. Kang, S. G., Chung, H., Hyon, J. Y. (1999). Experimental preretinal neovascularization by laser-induced thrombosis in albino rats. Korean J. Ophthalmol., 13(2), 65-70. doi: 10.3341/kjo.1999.13.2.65

25. Kretz, C. A., Vaezzadeh, N., Gross, P. L. (2010). Tissue factor and thrombosis models. Arterioscler. Thromb. Vasc. Biol., 30(5), 900-908. doi: 10.1161/ATVBAHA.108.177477 26. Vorwerk, D., Vollmer, B., Handt, S., Günther, R. W. (1994). Laser thermal venous obliteration: experimental results in the rat model. Rofo, 160(1), 84-88. doi: 10.1055/s2008-1032378

27. Millet, J., Theveniauxa, J., Pascala, M. (1987). A new experimental model of venous thrombosis in rats involving partial stasis and slight endothelium alterations. Thromb. Res., 45(Issue 2), 123-133.

28. Nakata, N., Kira, Y., Yabunaka, Y., Takaoka, K. Prevention of venous thrombosis by preoperative glycyrrhizin infusion in a rat model. (2008). J. Orthop. Sci., 13(5), 456-462. doi: 10.1007/s00776-008-1259-X

29. Ieki, Y., Nishiwaki, H., Miura, S., Hirata, Y., Sakata, I., Nonaka, A., ... Honda, Y. (2002). Quantitative evaluation for blood-retinal barrier breakdown in experimental retinal vein occlusion produced by photodynamic thrombosis using a new photosensitizer. Curr. Eye Res., 25(5), 317-323.

30. McGuinness, C. L., Humphries, J., Waltham, M., Burnand, K. G., Collins, M., Smith, A. (2001). Recruitment of labelled monocytes by experimental venous thrombosis. Thromb. Haemost., 85(6), 1018-1024.

31. Reyers, I., de Gaetano, G., Donati, M. B. (1989). Venostasis-induced thrombosis in rats is not influenced by circulating platelet or leukocyte number. Agents Actions, 28(1-2), 137-141.

32. Nagai, M., Yilmaz, C. E., Kirchhofer, D., Esmon, C. T., Mackman, N., Granger, D. N. (2010). Role of coagulation factors in cerebral venous sinus and cerebral microvascular thrombosis. Neurosurgery, 66(3), 560-565. doi: 10.1227/01. NEU.0000365745.49583.FD

33. Kaptanoglu, L., Kucuk, H. F., Colak, E., Kurt, N., Bingu, S. M., Akyol, H., ... Yazici, F. (2008). The effect of taurolidine on experimental thrombus formation. Eur. J. Pharmacol., 578(2-3), 238-241. doi: 10.1016/j. ejphar.2007.08.035

34. Meng, Q. Y., Li, X. Q., Yu, X. B., Lei, F. R., Jiang, K., Li, C. Y. (2010). Transplantation of VEGF165-genetransfected endothelial progenitor cells in the treatment of chronic venous thrombosis in rats. Chin. Med. J. (Engl.), 23(4), 471-477.

35. Ungersböck, K., Heimann, A., Kempski, O. (1993). Cerebral blood flow alterations in a rat model of cerebral sinus thrombosis. Stroke, 24(4), 563-569.

36. Moaveni, D. K., Lynch, E. M., Luke, C., Sood, V., Upchurch, G. R., Wakefield, T. W., Henke, P. K. (2008). Vein wall re-endothelialization after deep vein thrombosis is improved with low-molecular-weight heparin. J. Vasc. Surg., 47(3), 616-624. doi: 10.1016/j.jvs.2007.11.040

37. Sood, V., Luke, C., Miller, E., Mitsuya, M., Upchurch, G. R. Jr, Wakefield, T. W., ... Henke, P. K. (2010). Vein wall remodeling after deep vein thrombosis: differential effects of low molecular weight heparin and doxycycline. Ann. Vasc. Surg., 24(2), 233-241. doi: 10.1016/j.avsg.2009.11.002

38. Hisada, Y., Geddings, J. E., Ay, C., Mackman, N. (2015). Venous thrombosis and cancer: from mouse models to clinical trials. J. Thromb. Haemost., 13, 1372-1382. doi: 10.1111/jth.13009

39. Weitz, J. I., Eikelboom, J. W., Samama, M. M. (2012). New antithrombotic drugs: Antithrombotic Therapy and Prevention of Thrombosis, 9th ed.: American College of Chest Physicians Evidence-Based Clinical Practice Guidelines. Chest, 141(2 suppl.), e120S-e151S. doi: 10.1378/chest.11-2294

40. Wessler, S., Reimer, S. M., Sheps, M. C. (1959). Biological assay of a thrombosis inducing activity in human serum. J. Appl. Physiol., 14, 943-946. 